Journal of Strategic Security

Volume 8

Number 3 Volume 8, No. 3, Special Issue

Fall 2015: Intelligence: Analysis,

Tradecraft, Training, Education, and

Practical Application

\title{
The Black Banners: The Inside Story of 9/11 and the War Against al-Qaeda by Ali H. Soufan. London, New York, W.W. Norton \& Company, 2011.
}

Leland R. Erickson

Henley-Putnam University

Follow this and additional works at: https://digitalcommons.usf.edu/jss

pp. 140-142

\section{Recommended Citation}

Erickson, Leland R.. "The Black Banners: The Inside Story of 9/11 and the War Against al-Qaeda by Ali H. Soufan. London, New York, W.W. Norton \& Company, 2011.." Journal of Strategic Security 8, no. 3 (2015) : 140-142. DOI: http://dx.doi.org/10.5038/1944-0472.8.3.1465 Available at: https://digitalcommons.usf.edu/jss/vol8/iss3/9

This Book Review is brought to you for free and open access by the Open Access Journals at Digital Commons @ University of South Florida. It has been accepted for inclusion in Journal of Strategic Security by an authorized editor of Digital Commons @ University of South Florida. For more information, please contact digitalcommons@usf.edu. 


\section{The Black Banners: The Inside Story of 9/11 and the War}

Against al-Qaeda by Ali H. Soufan. London, New York, W.W.

Norton \& Company, 2011. 


\section{The Black Banners: The Inside Story of 9/11 and the War Against al-Qaeda by Ali H. Soufan. London, New York, W.W. Norton \& Company, 2011.}

Former FBI Special Agent Ali H. Soufan was a devoted law enforcement professional and patriotic American dedicated to our nation's safety and security. Soufan is an American Muslim of Lebanese descent. He was born in Beirut, is fluent in Arabic, and is studied in the Quran and a respectable number of the hadith. Years before 9/11, Soufan recognized the extreme, twisted ideology of al-Qaida (AQ) for what it was and he understood too well the nature of those who adhered to such a Manichean ideology and the threat posed by such fanatics to the security of the United States. This book is Soufan's autobiographical accounting of his career with the FBI in pursuit of $\mathrm{AQ}$ and Usama bin Laden.

The title of Soufan's narrative is a reference to a specific hadith that is a favorite of members of AQ. A hadith is a written record of a saying, act, or deed attributed to the Prophet Muhammad. The particular hadith mentioned in the title of Soufan's narrative is of dubious origins, one that mainstream Muslim scholars dismiss as inauthentic.

Khurasan refers to the region that is now modern northeastern and eastern Iran, some parts of Turkmenistan, Uzbekistan, Tajikistan, Afghanistan, and northwestern Pakistan, while Baitul Maqdis is another name for Jerusalem. The region has historical significance within the Muslim world. Khurasan was a major Muslim power, a center of commerce and trade, and hub of multi-cultural Muslim civilization. Today, what was once Khurasan is the home of the Afghani and Pakistani Taliban, and was the refuge and original operational ground of AQ and Usama bin Laden. The popularity of this particular hadith with $\mathrm{AQ}$ members is therefore apparent.

The Black Banners takes the reader through Sofan's career as an FBI interrogator in pursuit of AQ, chronicling the course of the FBI's counterterrorism efforts directed at AQ beginning with Soufan's recognition in the late 1990s of the danger posed by AQ to the security of the United States and the safety of the American people. The narrative moves through his critical role in the investigation of the bombing of the U.S.S. Cole in Yemen, to the terrible events of September 11, 2001, and Soufan's part in the pursuit of Usama bin Laden and his followers after that terrible day. It is a narrative rich in detail despite the amount of redacted content, a situation that the author addresses in the first page of the book. 
Ali H. Soufan was one of only a handful of FBI agents who spoke Arabic before 9/11. Long before the world would watch two airliners crash into the towers of the World Trade Center on live television, Soufan was following a group of violent extremists with increasing concern, tracking their activities, their public pronouncements, and their acts of terrorism in the pursuit of their cause. Like any dedicated counterterrorism professional, Soufan took a page straight from Sun Tzu's timeless Art of War, to "Know your enemy as you know yourself." Ali Soufan's depth and intimacy of knowledge of what motivated these particular extremists genuinely worried him, as these radicalized individuals had already shown they were not merely willing, but able to deliver on their threats (and were going to persist in their efforts until they succeeded or died trying).

To the members of this group - euphemistically named al-Qaida (Arabic, lit. "the [military] Base") and including the group's leader Usama bin Ladenthey were all doing God's holy work, fighting the very forces of Satan in a cosmic war between good and evil. Soufan understood this dimension of the radicalized Islamist mind thoroughly, and thus recognized that Usama bin Laden's 1998 fatwah declaring war on the United States and the American people was a very real threat that bin Laden and his followers fully intended to carry out.

Bin Laden alleged that the United States was "guilty" of a number of "crimes" including deploying troops on the sacred soil of the Muslim holy land that encompasses the twin holy cities of Mecca and Medina within Saudi Arabia. This violated the belief of the radical Wahhabi fundamentalist branch of Islam that bin Laden and his followers subscribed to forbidding the presence of "infidels" in the Muslim holy land. That the United States military was present in Saudi Arabia at the behest of the Saudi government due to the continuing threat to regional security posed by Iraqi dictator Saddam Hussein did not moderate bin Laden's judgment. Firm in his belief that no "infidel" should ever set foot in the Muslim holy land, bin Laden declared that the punishment was death for such an unforgivable transgression, both for the infidels and anyone who aided and abetted them. Bin Laden thus regarded the Royal House of Saud as apostate for failing to act in strict adherence to the extremist Wahhabi creed, and it was therefore no longer fit to rule over Mecca and Medina.

Soufan's narrative takes the reader through his work as one of the FBI's dedicated counterterrorism investigators and interrogation professionals. A 
passionate advocate of the informed interrogation techniques used by the FBI and American law enforcement for decades, and a no less passionate opponent of the so-called "enhanced interrogation techniques," including waterboarding, Soufan describes clearly and concisely how he and his fellow agents interrogated such AQ notables as Abu Zubaydah, Abu Jandal, Jamal al-Badawi, Ali al-Bahlul, and Salim Hamdan. In each case, Soufan elicited vital intelligence from his subjects without the use of physical force and without employing physical coercion in any form. In contrast, Khalid Sheik Muhammad continued to lie about the identity of a critical AQ courier even after he had been waterboarded 183 times. It was through Soufan's interrogation of Abu Zubaydah that U.S. authorities learned that Khalid Sheik Muhammad was a member of AQ and the mastermind of the 9/11 plot.

The Black Banners serves as a tremendously informative counterterrorism professional's narrative of the events leading up to and following 9/11. The book is also a powerful indictment of Enhanced Interrogation Techniques, not simply because they are immoral and contrary to the American character, but because as history has shown time and again, and as Ali H. Soufan and his colleagues witnessed, torture simply does not yield reliable, actionable intelligence in a timely fashion. The Black Banners is furthermore a chronicle of the sort of inter-service rivalries and counterproductive assumptions founded on a lack of knowledge of the opposition that disrupt or can even derail counterterrorism efforts with tragic consequences. Soufan's work was awarded the 2012 Ridenhour Book Prize honoring "an outstanding work of social significance..." It is in this reviewer's estimation a well-deserved honor, as The Black Banners belongs on the book self of anyone who cares not only about the events of 9/11, but how best to combat terrorism effectively and prevent such tragic events from ever occurring.

Leland R. Erickson, Henley-Putnam University 